\title{
Size-fractionated uptake of ammonium, nitrate and urea and phytoplankton growth in the North Sea during spring 1994
}

\author{
Roel Riegman ${ }^{1, *}$, Inez A. Flameling ${ }^{2}$, Anna A. M. Noordeloos ${ }^{1}$ \\ 'Netherlands Institute for Sea Research (NIOZ), PO Box 59, $1790 \mathrm{AB}$ Den Burg, The Netherlands \\ ${ }^{2}$ NIOO-CEMO, Vierstraat 28, 4401 EA Yerseke, The Netherlands
}

\begin{abstract}
The growth of 2 different algal size classes was studied in March/April 1994 during the establishment of the spring bloom along a transect from the Dogger Bank to the Shetland Islands in the North Sea. Size-differential growth rates were estimated on the basis of independent measurements of carbon and nitrogen uptake. At the shallower stations near the Dogger Bank (DB) area, chlorophyll $a$ (chl a) levels were up to $5.8 \mu \mathrm{g} \mathrm{l}^{-1}$. In the bloom $89 \%$ of the chl a was in the $>5 \mu \mathrm{m}$ fraction. In the central North Sea (cNS) and near the Shetland Islands (SI) total chl a was 0.52 and $0.38 \mu \mathrm{g} \mathrm{l}^{-1}$, respectively; $60 \%$ was in the $>5 \mu \mathrm{m}$ fraction. Depth-integrated primary production at the DB, CNS and SI was 46,145 and $149 \mathrm{mg} \mathrm{C} \mathrm{m}^{-2} \mathrm{~d}^{-1}$, respectively, for the $<5 \mu \mathrm{m}$ fraction, and 392,254 , and $282 \mathrm{mg} \mathrm{C} \mathrm{m}^{-2} \mathrm{~d}^{-1}$ for the total phytoplankton communities $(n=6,24$ and 8 , respectively). The major nitrogen source was nitrate according to ${ }^{15} \mathrm{~N}$ uptake. The average $f$-ratios calculated from nitrate uptake al, respectively, the DB, cNS and SI were $83(n=4), 71(n=12)$, and $61 \%(n=5)$ of the total nitrogen uptake by the total phytoplankton community. The $<5 \mu \mathrm{m}$ fraction had a lower preference for nitrate except for the populations near the Shetland Islands with values of $71(n=4), 63(n=12)$, and $62 \%(n=5)$, respectively, of the total nitrogen uptake. Ammonium was taken up about twice as fast as urea by both the $<5 \mu \mathrm{m}$ and the total fraction. The average specific growth rate of phytoplankton, calculated on the basis of nitrogen uptake, along the transect was $0.27 \pm 0.11 \mathrm{~d}^{-1}(\mathrm{n}=36)$ for the $<5 \mu \mathrm{m}$ fraction with a maximum value of $0.73 \mathrm{~d}^{-1}$. The larger size fraction had a significantly $(p<0.0005)$ lower average specific growth rate $(0.17 \pm$ $0.11 \mathrm{~d}^{-1}$ ) with a maximum value of $0.70 \mathrm{~d}^{-1}$ The chl a specific carbon uptake rates yielded similar estimates of the specific growth rate: $0.29 \pm 0.10 \mathrm{~d}^{-1}(\mathrm{n}=28)$ for the smaller size fraction and $0.15 \pm 0.05 \mathrm{~d}^{-1}$ $(n=28)$ for the $>5 \mu \mathrm{m}$ size fraction. Since the calculated specific growth rates, based on either nitrogen uptake or inorganic carbon uptake, were in good agreement with each other for both size fractions, it was concluded that smaller algae apparently grow faster than larger ones in this typically lightcontrolled environment. The $>5 \mu \mathrm{m}$ fraction, however, dominated the bloom at the Dogger Bank. Our findings consolidate the concept of size differential control of phytoplankton communities under typical spring bloom conditions which originally was demonstrated in a coastal area (Riegman et al. 1993; Neth J Sea Res 31:255-265).
\end{abstract}

KEY WORDS: Phytoplankton growth $\cdot$ Size fractionation $\cdot$ Nitrogen uptake $\cdot$ Carbon uptake $\cdot$ North Sea

\section{INTRODUCTION}

An increase in incident daily irradiance triggers the spring bloom of phytoplankton. The increase of biomass is mainly attributed to diatoms having larger cell size than the predominant pico- and micro- algae of winter populations (Raimbault et al. 1988, Chisholm

\footnotetext{
•E-mail: riegman@nioz.nl
}

1992, Riegman et al. 1993). Classical explanations for the shift in dominance towards larger cell size classes are related to the competitive ability of diatoms and their reduced sedimentation losses in turbulent waters (Margalef 1978). It is obvious that the disadvantage of higher intrinsic sedimentation rates of larger diatoms diminishes in turbulent waters. There are even larger diatoms which are capable of becoming positively buoyant (Fisher \& Harrison 1996, Moore \& Villareal 1996). However, low sedimentation losses of larger 
diatoms still do not explain their dominance under turbulent conditions, since the sedimentation losses of pico-, and usually motile micro-algae, are also low in turbulent waters. Therefore size differential biomass accumulation in turbulent waters might be explainable by other species specific fitness factors such as competitive ability and sensitivity to grazing pressure.

For both freshwater (Sommer 1989) and marine species (Riegman et al. 1996), it has been demonstrated that, amongst various taxonomic groups, diatoms are superior competitors for light and nutrients if silicate is available. Characteristic for spring blooms is that they are established under light-limiting growth conditions (Riegman et al. 1993, Rees et al. 1995). Measurements on the specific growth rate are surprisingly rare, but those reported indicate a specific growth rate which is about 30 to $50 \%$ of the maximum growth rate which could be achieved at the ambient temperature and nutrient concentrations (Epply 1972). Theoretically, smaller cells are better competitors for light than larger ones. This is because the energy requirement for cell synthesis increases to a larger extent with cell size than the cellular photon absorption (Raven 1984). Thus, on the basis of competition alone, it would be expected that spring blooms would be dominated by diatom species which have a small cell size.

In contrast to copepods, microzooplankton is usually present in significant amounts during the establishment of the spring bloom (Verity 1986, Riegman et al. 1993). In a previous study, we measured a herbivoric grazing pressure up to $0.38 \mathrm{~d}^{-1}$ during the establishment of a spring bloom in the Dutch coastal area (Riegman et al. 1993). Elimination of microzooplankton by serial dilution resulted in a dominance of algae $<8 \mu \mathrm{m}$, whereas the untreated controls were dominated by larger algae similar to natural conditions when microzooplankton was present (Riegman et al. 1993).

The concept of size differential control of phytoplankton (Riegman et al. 1993) implies that in the same watermass the biomass of algae in different size classes can be regulated by different controlling factors. That is, the biomass of small algae can be controlled by grazing, whereas the biomass of larger phytoplankton is mainly regulated by the balance between growth and sedimentation rates. This concept has been a successful theoretical framework for the analysis of foodweb dynamics (Thingstad \& Sakshaug 1990) and the interpretation of seasonal succession of algal species in the North Atlantic (Taylor et al. 1993). Although the arguments for size differential control have been described extensively by various authors (e.g. Thingstad \& Sakshaug 1990, Kiørboe 1993, Riegman et al. 1993), the actual evidence, based on real measurements on size differential growth rates of natural populations, is still very restricted.
Here we present the results of a study on the growth rates of 2 different algal size classes during the establishment of the spring bloom along a transect from the Dogger Bank to the Shetland Islands in the North Sea. Size differential growth rates were measured on the basis of independent measurements of carbon and nitrogen uptake. Nitrogen uptake was monitored for ammonium, nitrate and urea since size differential preference has been reported (Koike et al. 1981, Probyn 1985). The relative preference index (RPI; McCarthy et al. 1977), indicating the preferential uptake of ammonium (above other nitrogen sources), has been found to be higher in smaller size fractions (Probyn 1985). However, this might be due to the contribution of bacterial ammonium uptake in the smallest size fraction. Since the specific algal growth rate cannot be concluded from the RPI, and the RPI is only weakly related to a physiological preference (Stolte \& Riegman 1996), we preferred to use the sum of ammonium, nitrate and urea uptake, relative to particulate nitrogen, as an indicator for the specific growth rate of algae in the different size classes. The 2 independent estimations of algal growth rate (based on carbon and nitrogen uptake) were used to explore the hypothesis that smaller algae grow faster than larger ones as previously predicted (Raven 1984) and demonstrated for laboratory cultures (Chan 1978, Blasco et al. 1982), and in a coastal ecosystem (Riegman et al. 1993).

\section{MATERIAL AND METHODS}

The cruise track between the Dogger Bank (North Sea) and the Shetland Islands is shown in Fig. 1. Along the transect there were 7 main stations ( $\mathrm{HO}$ to $\mathrm{H} 7$ ). Additionally, there were 6 sub-stations (N1 to N6) located in between these main stations, and 16 substations located $32 \mathrm{~km}$ eastwards (EO to E7) and westwards ( $\mathrm{W} 0$ to W7) of the main stations. At all stations CTD profiles were obtained to provide information on temperature, light attenuation, turbidity and fluorescence between. 28 March and 12 April 1994. At various depths, samples were taken with NOEX bottles for carbon fixation (2 depths), chl $a$ and nutrients $(5,10$, 20 , and $40 \mathrm{~m}$ ).

Incident solar irradiance was measured for 2 wk on board ship, using a Kipp Solarimeter. The photosynthetically available radiation (PAR) was calculated from the average daily irradiance assuming PAR to be $45 \%$ of the total irradiance and expressed as $\mathrm{J} \mathrm{m}^{-2} \mathrm{~s}^{-1}$ (Lüning 1981). Light reflection at the sea surface was assumed to be $3 \%$ of the total irradiance (Vermij 1987). The underwater scalar attenuation coefficient $\left(K_{d}, \mathrm{~m}^{-1}\right)$ was calculated from underwater PAR quantum measurements and fitted according to the Lambert-Beer law. 


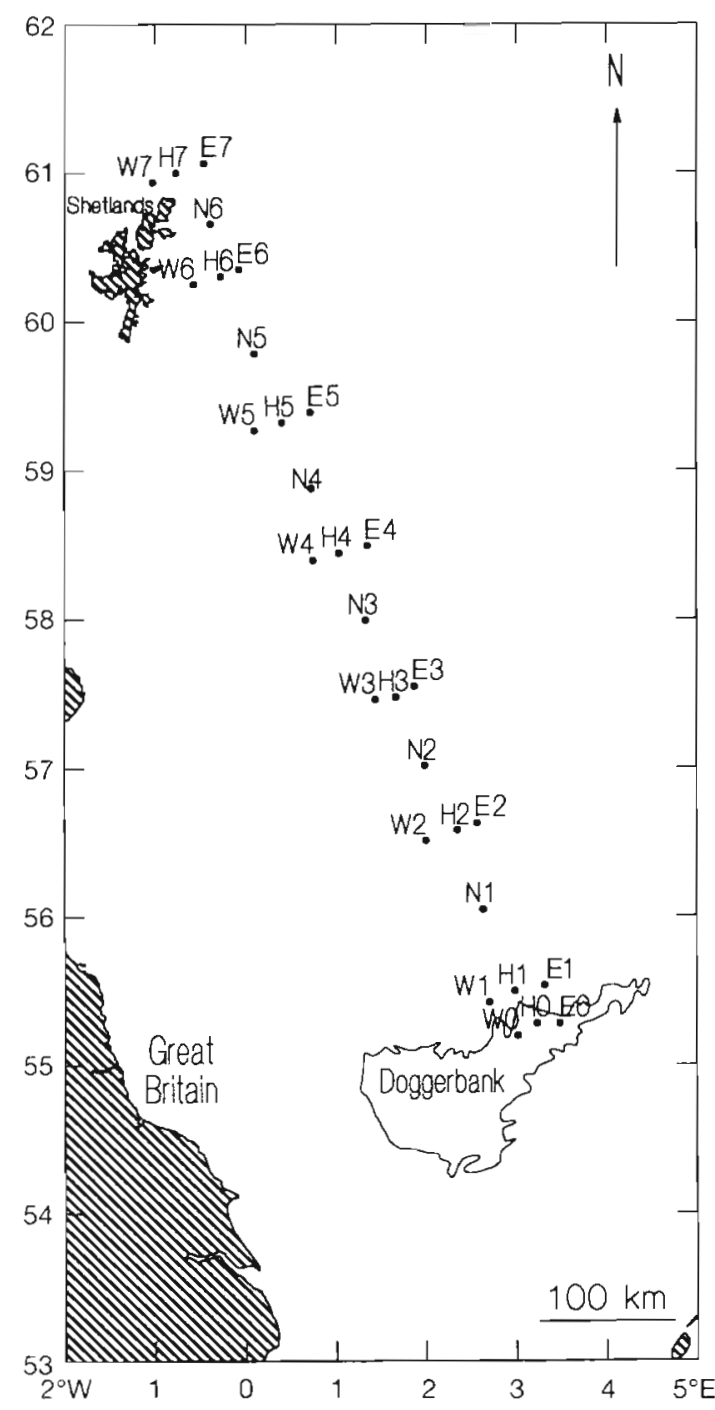

Fig. 1. Transect with the sampling stations along the transect from the Dogger Bank to the Shetland Islands (North Sea) visited in April/May 1994

$\mathrm{NH}_{4}, \mathrm{NO}_{3}$, and urea were measured with a TRAA autoanalyser system. $\mathrm{NH}_{4}$ was detected immediately after sampling as indo-phenolblue-complex ( $\mathrm{pH} 10.5)$ at $630 \mathrm{~nm}$ (Helder \& de Vries 1979); $\mathrm{NO}_{3}$ was reduced in a copper cadmium coil to nitrite (using imidazole as a buffer) and then measured as nitrite. $\mathrm{NO}_{2}$ was detected after diazotation with sulphanilamide and $\mathrm{N}$ (1-naphtyl)-ethylene diammonium dichloride as the reddish purple dye complex at $540 \mathrm{~nm}$ (Grasshoff 1967). Urea was determined within 1 mo after storage at $-30^{\circ} \mathrm{C}$ and measured at $520 \mathrm{~nm}$ after condensation with diacetylmonoxime to form a pink coloured complex using thiosemicarbazide to intensify and ferrichloride to stabilize the colour.

Samples for chl a analysis were collected by filtration (Whatman GF/F for unfractionated phytoplankton and by polycarbonate filters ( $5 \mu \mathrm{m}$, Poretics) for the $>5 \mu \mathrm{m}$ fraction) and analyzed on board fluorometrically according to the method of Holm-Hansen et al. (1965).

Carbon fixation was estimated using the ${ }^{14} \mathrm{C}$ technique (Riegman \& Colijn 1991).

Water samples were taken from 2 different depths (at $10 \mathrm{~m}$, and at $40 \mathrm{~m}$ or at the fluorescence maximum if present) and subdivided in $50 \mathrm{ml}$ subsamples. Prior to incubation $5 \mu \mathrm{Ci} \mathrm{NaH}^{14} \mathrm{CO}_{3}$ (Amersham) was added to subsamples in an irradiance gradient incubator at in situ temperatures. The incubator was illuminated with an Osram metallogen HMI $1200 \mathrm{~W}$ lamp, the spectrum of which closely resembles that of natural sunlight (Colijn 1983). Different irradiances were achieved using neutral density filters (Lee, Andover, UK). The side walls of the incubation vessels (tissue culture bottles; Greiner, Solingen, Germany) were covered with black tape to ensure illumination exclusively from the front. It was concluded from previous tests that this precaution improved the reproducibility of P/I (photosynthesis/irradiance) measurements. Irradiances were measured prior to every incubation using a Licor LI-192 SA underwater Quantum sensor. Calculation of the average irradiance of each vessel was based on in-and outcoming irradiance which was measured for each incubation series. For the establishment of one $\mathrm{P} / \mathrm{I}$ relationship at least 7 irradiances (ranging from 10 to $3000 \mu \mathrm{E} \mathrm{m}^{-2} \mathrm{~s}^{-1}$ ) were used. After incubation for $2 \mathrm{~h}$, samples were filtered through $5 \mu \mathrm{m}$ pore size Poretics polycarbonate membrane filters and the filtrate across Whatman GF/F filters with a gentle filtration pressure $(-12 \mathrm{kPa}$ relative to atmospheric pressure) to obtain size-fractionated carbon fixation rates. Filters were fumed over conc. $\mathrm{HCl}$ for at least $10 \mathrm{~min}$ and counted in a liquid scintillation counter after addition of $10 \mathrm{ml}$ Instagel II (Packard Canberra). Total inorganic carbon was determined with a TOC analyzer (model 700; IO Corporation, College Station, TX, USA).

Filter absorption was found to be negligible. Dark values, never exceeding $5 \%$ of the maximum photosynthesis rate, were not subtracted from light values (Mortain-Bertrand et al. 1988).

P/I curves were fitted according to Platt et al. (1980). Daily carbon fixation profiles were calculated from the average PAR, $K_{\mathrm{d}}$, the measured P/I relationship from the $10 \mathrm{~m}$ sample for the upper $30 \mathrm{~m}$ of the water column and the measured $\mathrm{P} / \mathrm{I}$ relationship from the $40 \mathrm{~m}$ sample for the remaining part of the water column, and corrected for the vertical distribution of phytoplankton as indicated by the fluorescence measurements. This incubator method has been found to deviate by less than 10\% from in situ measurements (Riegman \& Colijn 1991).

Nitrate, ammonium and urea incorporation rates were estimated using ${ }^{15} \mathrm{~N}$. From $10 \mathrm{~m}$ and $40 \mathrm{~m}$ depth, 1 l 
samples were spiked with either ${ }^{15} \mathrm{NH}_{4}{ }^{+},{ }^{15} \mathrm{NO}_{3}{ }^{-}$or ${ }^{15} \mathrm{~N}$-urea added in trace amounts and incubated in polycarbonate bottles. We enriched the samples with $10 \%$ of the ambient concentration, subjected to a minimum of $0.1 \mu \mathrm{M}$. We corrected for this enrichment assuming that the nutrient uptake rate is linearly related to its concentration. The bottles were incubated at in situ temperature $\left(9\right.$ to $\left.12^{\circ} \mathrm{C}\right)$ and a photon flux density of $60 \mu \mathrm{E} \mathrm{m} \mathrm{m}^{-2} \mathrm{~s}^{-1}$, corresponding to $10 \mathrm{~m}$ depth, or $10 \mu \mathrm{E}$ $\mathrm{m}^{-2} \mathrm{~s}^{-1}$, corresponding to $40 \mathrm{~m}$ depth. After $2 \mathrm{~h}$, the incubation was terminated by filtration of $300 \mathrm{ml}$ samples using maximally $-12 \mathrm{kPa}$. Filtration through a precombusted Whatman GF/F filter was performed to obtain the uptake by total particulate material. The $<5 \mu \mathrm{m}$ fraction was collected on a precombusted Whatman GF/F filter after filtration through a $5 \mu \mathrm{m}$ pore size polycarbonate filter (Poretics). The filters were stored at $-50^{\circ} \mathrm{C}$ for no longer than 3 mo before analysis. Filters were then dried and acidified twice with $\mathrm{H}_{2} \mathrm{SO}_{3}$ to remove inorganic carbon. Particulate carbon, nitrogen and $\delta^{15} \mathrm{~N}$ were determined using a Carlo Erba Instruments NA 1500 Series 2 CNS Analyzer on line with a VG Isotech Optima Stable Isotope Mass Spectrometer. ${ }^{15} \mathrm{~N}$ incorporation rates were calculated after Dugdale \& Goering (1967).

The specific growth rate of phytoplankton $\left(\mu_{\mathrm{N}}\right)$. based on hourly nitrogen uptake in the light, was calculated by division of the total inorganic nitrogen uptake rate by chl a and a cellular $\mathrm{N} / \mathrm{chl}$ a ratio of 6.05 $\left(\mu \mathrm{g} \mu \mathrm{g}^{-1}\right)$. This ratio was calculated from the average total particulate $\mathrm{N} /$ total chl a ratio measured at all stations. This hourly based specific growth rate was converted to a daily rate by multiplying by 24 . Additionally, the daily specific growth rate was multiplied by $5 / 8$, assuming that the algae experienced light only during $12 \mathrm{~h}$ of the day at which they would take up nitrogen at the same rate as under the experimental conditions. During the $12 \mathrm{~h}$ dark period, it was assumed that the nitrogen uptake rate would be $25 \%$ of the measured uptake rate in the light.

The specific growth rate of algae, based on the measured inorganic carbon fixation rates $\left(\mu_{\mathrm{C}}\right)$, was calculated by division of the carbon fixation of the watercolumn by the product of mixing depth and chl a concentration, and a $\mathrm{C} / \mathrm{chl}$ a ratio of 25 (Gieskes \& Kraay 1984, Riegman et al. 1993). Additionally, this apparent growth rate was multiplied by 0.5 to yield the estimated specific growth rate. This factor 0.5 was based on the assumptions that during the $12 \mathrm{~h}$ dark period no carbon was fixed, that storage products are converted into new cell material with an efficiency in cell synthesis of $33 \%$ in order to maintain the same growth rate in the dark period. (Riegman 1985), and that the specific growth rate in the dark period (supported by conversion of storage products) was equal to the specific growth rate in the light period. Primary production was calculated as the product of the specific growth rate (calculated as average from $\mu_{C}$ and $\left.\mu_{N}\right)$, the mixing depth, chl a and a C/chl a ratio of 25 (Gieskes \& Kraay 1984).

\section{RESULTS}

The CTD profiles indicated a homogenous vertical distribution of conductivity and temperature (data not shown) at all stations down to $5 \mathrm{~m}$ above the bottom. At the northern part of the transect, where the inflow of nutrient-rich ocean water occurs, the highest nutrient concentrations were observed (Table 1). From north to south, nitrate declined from $11 \mu \mathrm{M}$ to $0.3 \mu \mathrm{M}$ on top of the Dogger Bank. Ammonium and urea were generally low (below $0.15 \mu \mathrm{M}$ ) with the majority of the area being characterized by average values of $0.06 \pm 0.04 \mu \mathrm{M}$ $(n=24)$ for ammonium and $0.04 \pm 0.03 \mu \mathrm{M}(\mathrm{n}=24)$ for urea. The observed lower values of nitrate between the southern stations $\mathrm{HO}$ and $\mathrm{N} 2$ coincided with enhanced chl a values (Table 1). At the deeper stations (H3 to W7. average depth $=119 \pm 20 \mathrm{~m}$ ) total chl a was vertically distributed homogeneously at values of $0.4 \mu^{\mu g^{-1}}$ with mixing depths greater than $80 \mathrm{~m}$. Higher values were observed at shallower stations, with a maximum of $5.9 \mu \mathrm{g} \mathrm{l}^{-1}$ at Stn $\mathrm{H} 1$ at the northern slope of the Dogger Bank. This phytoplankton spring bloom consisted mainly of algae larger than $5 \mu \mathrm{m}$. The $<5 \mu \mathrm{m}$ size fraction varied between 0.1 and $0.7 \mu \mathrm{gl}^{-1}$, whereas the $>5 \mu \mathrm{m}$ size fraction varied between 0.1 and $9.1 \mu \mathrm{g} \mathrm{l}^{-1}$

The total nitrogen uptake rate (Fig. 2) showed a comparable distribution to chl a. Low values were found at the Stns $\mathrm{H} 3$ to $\mathrm{W} 7\left(0.09 \pm 0.09 \mu \mathrm{g} \mathrm{N} l^{-1} \mathrm{~h}^{-1} ; \mathrm{n}=24\right)$. In the bloom over the Dogger Bank, higher values up to $0.69 \mu \mathrm{g} \mathrm{N} \mathrm{l}^{-1} \mathrm{~h}^{-1}$ were measured for the total plankton

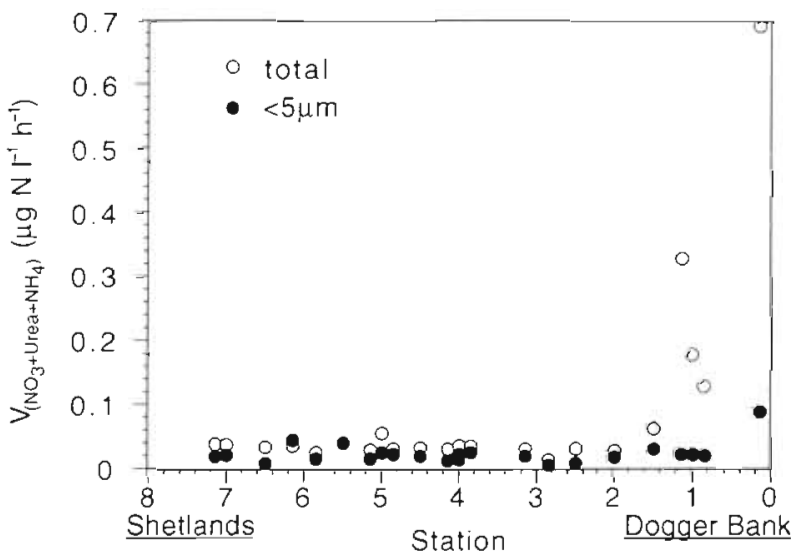

Fig. 2. Total nitrogen uptake rate in samples collected at $10 \mathrm{~m}$ depth, by the $<5 \mu \mathrm{m}$ fraction ( $)$ and total community (o) along the transect 
Table 1. Dissolved nitrogen concentrations, total nitrogen uptake rates $(V)$ and chlorophyll a (chl a) at $10 \mathrm{~m}$ depth; and gross carbon fixation rates (CFR) at the various stations along the transect from the Dogger Bank to the Shetland Islands in March/April 1994

\begin{tabular}{|c|c|c|c|c|c|c|c|c|c|c|c|}
\hline \multirow[t]{2}{*}{$\begin{array}{l}\text { Station } \\
\text { no. }\end{array}$} & \multirow{2}{*}{$\begin{array}{l}\text { Location } \\
\text { Lat. (N)/Long. (E) }\end{array}$} & $\mathrm{NH}_{4}^{+}$ & & \multirow[b]{2}{*}{-} & $V_{\mathrm{NH}_{4}}{ }^{*}$ & $V_{\mathrm{NO}_{3}}^{-}$ & $V_{\text {urea }}$ & $\begin{array}{r}\text { Chl a } \\
<5 \mu \mathrm{m}\end{array}$ & $\begin{array}{l}\text { Chl a } \\
\text { total }\end{array}$ & \multirow{2}{*}{$\begin{array}{l}\text { CFR } \\
<5 \mu \mathrm{m} \\
\text { (g C m }\end{array}$} & \multirow{2}{*}{$\begin{array}{r}\text { CFR } \\
\text { total } \\
\left.-2 d^{-1}\right)\end{array}$} \\
\hline & & \multicolumn{2}{|c|}{$\longrightarrow(\mu \mathrm{M})-$} & & \multicolumn{3}{|c|}{$\longrightarrow\left(\mathrm{mg} \mathrm{N} \mathrm{m}^{-3} \mathrm{~h}^{-1}\right) \longrightarrow$} & \multicolumn{2}{|c|}{$-\left(\mu \mathrm{gl}^{-1}\right)-$} & & \\
\hline $\mathrm{HO}$ & $55^{\circ} 17^{\prime} 04^{\prime \prime} / 3^{\circ} 14^{\prime} 60^{\prime \prime}$ & - & 0.12 & - & - & - & - & - & - & - & - \\
\hline $\mathrm{H} 1$ & $55^{\circ} 29^{\prime} 68^{\prime \prime} / 2^{\circ} 52^{\prime} 68^{\prime \prime}$ & 0.04 & 3.70 & 0.056 & 0.025 & 0.136 & 0.015 & 0.15 & 5.90 & - & - \\
\hline E1 & $55^{\circ} 32^{\prime} 64^{\prime \prime} / 3^{\circ} 19^{\prime} 07^{\prime \prime}$ & 0.01 & 4.43 & 0.036 & 0.004 & 0.116 & 0.007 & 0.33 & 3.40 & - & - \\
\hline W1 & $55^{\circ} 25^{\prime} 92^{\prime \prime} / 2^{\circ} 42^{\prime} 88^{\prime \prime}$ & 0.06 & 3.75 & 0.026 & 0.037 & 0.285 & 0.006 & 0.39 & 9.01 & 0.11 & 0.44 \\
\hline N1 & $56^{\circ} 02^{\prime} 93^{\prime \prime} / 2^{\circ} 38^{\prime} 94^{\prime \prime}$ & 0.09 & 6.83 & 0.001 & 0.018 & 0.045 & $<0.001$ & 0.27 & 1.42 & 0.21 & 0.77 \\
\hline $\mathrm{H} 2$ & $56^{\circ} 39^{\prime} 05^{\prime \prime} / 2^{\circ} 21^{\prime} 18^{\prime \prime}$ & 0.02 & 7.79 & 0.044 & 0.002 & 0.026 & 0.001 & 0.33 & 0.51 & - & - \\
\hline $\mathrm{E} 2$ & $56^{\circ} 37^{\prime} 96^{\prime \prime} / 2^{\circ} 35^{\prime} 14^{\prime \prime}$ & - & - & - & - & - & - & - & - & - & - \\
\hline W2 & $56^{\circ} 31^{\prime} 19^{\prime \prime} / 2^{\circ} 01^{\prime} 97^{\prime \prime}$ & - & - & - & - & - & - & 0.27 & 0.57 & 0.27 & 0.31 \\
\hline N2 & $57^{\circ} 00^{\prime} 85^{\prime \prime} / 1^{\circ} 59^{\prime} 93^{\prime \prime}$ & 0.02 & 6.45 & 0.020 & 0.003 & 0.024 & 0.005 & 0.72 & 2.13 & 0.40 & 0.50 \\
\hline $\mathrm{H} 3$ & $57^{\circ} 29^{\prime} 67^{\prime \prime} / 1^{\circ} 40^{\prime} 17^{\prime \prime}$ & - & - & - & - & - & - & 0.19 & 0.34 & 0.21 & 0.31 \\
\hline E3 & $57^{\circ} 33^{\prime} 99^{\prime \prime} / 1^{\circ} 53^{\prime} 01^{\prime \prime}$ & 0.02 & 8.66 & 0.016 & 0.002 & 0.011 & 0.002 & 0.28 & 0.42 & 0.18 & 0.31 \\
\hline W3 & $57^{\circ} 28^{\prime} 20^{\prime \prime} / 1^{\circ} 26^{\prime} 56^{\prime \prime}$ & 0.04 & 8.36 & 0.035 & 0.008 & 0.020 & 0.005 & 0.18 & 0.35 & 0.23 & 0.29 \\
\hline N3 & $57^{\circ} 59^{\prime} 28^{\prime \prime} / 1^{\circ} 21^{\prime} 07^{\prime \prime}$ & 0.02 & 9.12 & 0.078 & 0.002 & 0.020 & 0.005 & 0.14 & 0.36 & 0.27 & 0.33 \\
\hline $\mathrm{H} 4$ & $58^{\circ} 26^{\prime} 78^{\prime \prime} / 1^{\circ} 02^{\prime} 70^{\prime \prime}$ & 0.02 & 9.15 & 0.11 & 0.004 & 0.011 & 0.009 & 0.17 & 0.31 & 0.17 & 0.27 \\
\hline $\mathrm{E} 4$ & $58^{\circ} 29^{\prime} 82^{\prime \prime} / 1^{\circ} 21^{\prime} 67^{\prime \prime}$ & 0.02 & 9.05 & 0.082 & 0.005 & 0.022 & 0.009 & 0.22 & 0.37 & 0.05 & 0.15 \\
\hline W4 & $58^{\circ} 24^{\prime} 17^{\prime \prime} / 0^{\circ} 45^{\prime} 52^{\prime \prime}$ & 0.02 & 8.6 & 0.049 & 0.004 & 0.021 & 0.008 & 0.14 & 0.59 & 0.15 & 0.35 \\
\hline N4 & $58^{\circ} 53^{\prime} 06^{\prime \prime} 10^{\circ} 44^{\prime} 03^{\prime \prime}$ & 0.05 & 8.73 & 0.015 & 0.008 & 0.024 & 0.002 & 0.12 & 0.41 & - & - \\
\hline $\mathrm{H} 5$ & $59^{\circ} 19^{\prime} 60^{\prime \prime} / 0^{\circ} 23^{\prime} 63^{\prime \prime}$ & 0.06 & 9.62 & 0.001 & 0.021 & 0.036 & $<0.001$ & 0.27 & 0.32 & 0.26 & 0.47 \\
\hline E5 & $59^{\circ} 24^{\prime} 06^{\prime \prime} / 0^{\circ} 43^{\prime} 61^{\prime \prime}$ & 0.05 & 9.03 & 0.001 & 0.008 & 0.025 & $<0.001$ & 0.19 & 0.33 & 0.26 & 0.37 \\
\hline W5 & $59^{\circ} 16^{\prime} 67^{\prime \prime} / 0^{\circ} 06^{\prime} 13^{\prime \prime}$ & 0.05 & 9.48 & 0.018 & 0.005 & 0.050 & 0.001 & 0.14 & 0.35 & 0.23 & 0.43 \\
\hline N5 & $59^{\circ} 47^{\prime} 32^{\prime \prime} / 0^{\circ} 06^{\prime} 31^{\prime \prime}$ & 0.11 & 10.1 & 0.012 & 0.013 & 0.023 & 0.001 & 0.14 & 0.46 & 0.40 & 0.69 \\
\hline $\mathrm{H} 6$ & $60^{\circ} 20^{\prime} 41^{\prime \prime} / 0^{\circ} 08^{\prime} 35^{\prime \prime}$ & - & - & - & - & - & - & 0.14 & 0.28 & 0.17 & 0.42 \\
\hline E6 & $60^{\circ} 21^{\prime} 12^{\prime \prime} / 0^{\circ} 03^{\prime} 16^{\prime \prime}$ & 0.11 & 11.5 & 0.054 & 0.008 & 0.063 & 0.002 & 0.15 & 0.30 & 0.18 & 0.36 \\
\hline W6 & $60^{\circ} 15^{\prime} 05^{\prime \prime} / 0^{\circ} 33^{\prime} 87^{\prime \prime}$ & 0.16 & 10.9 & 0.025 & 0.013 & 0.023 & 0.002 & 0.17 & 0.38 & 0.28 & 0.44 \\
\hline N6 & $60^{\circ} 39^{\prime} 97^{\prime \prime} / 0^{\circ} 23^{\prime} 03^{\prime \prime}$ & 0.14 & 10.9 & 0.064 & 0.014 & 0.017 & 0.003 & 0.18 & 0.47 & 0.25 & 0.48 \\
\hline $\mathrm{H} 7$ & $61^{\circ} 00^{\prime} 24^{\prime \prime} / 0^{\circ} 46^{\prime} 19^{\prime \prime}$ & 0.12 & 11.3 & 0.013 & 0.012 & 0.027 & 0.001 & 0.18 & 0.42 & 0.21 & 0.52 \\
\hline E7 & $61^{\circ} 03^{\prime} 64^{\prime \prime} / 0^{\circ} 26^{\prime} 44^{\prime \prime}$ & - & - & - & - & - & - & - & - & - & - \\
\hline W7 & $60^{\circ} 56^{\prime} 68^{\prime \prime} / 1^{\circ} 01^{\prime} 77^{\prime \prime}$ & 0.05 & 10.8 & 0.072 & 0.009 & 0.026 & 0.005 & 0.19 & 0.43 & - & - \\
\hline
\end{tabular}

fraction. The difference to the uptake rate of the $<5 \mu \mathrm{m}$ fraction (Fig. 2) indicated that the majority of nitrogen uptake was mediated by the $>5 \mu \mathrm{m}$ fraction in this spring bloom.

The main inorganic nitrogen component taken up by the plankton was nitrate. Remarkably, although nitrate was much lower at Stns $\mathrm{H} 0$ to $\mathrm{W} 1$ than at other stations, nitrogen uptake was mainly in the form of nitrate (Fig. 3). This could be explained by the size distribution of the community. At the stations with a low dominance of larger algae (Stns 7 to 3 ), the contribution of nitrate, urea, and ammonium was $68 \pm 9,10 \pm 8$ and $22 \pm 9 \%(n=18)$ of the total nitrogen uptake, respectively, for the total communities. Uptake by the $<5 \mu \mathrm{m}$ fraction (contributions of nitrate, urea, and ammonium were $65 \pm 11,10 \pm 7$ and $25 \pm 13 \%[n=18]$ of the total nitrogen uptake, respectively) showed a comparable speciation (Fig. 4) with a slightly higher preference for ammonium compared to the total community.

Larger phytoplankton dominated at Stns H1, E1,W1 and N1 near the Dogger Bank. At these stations, the preference for nitrate by the total community was more pronounced. For the total plankton community, the contribution of nitrate, urea, and ammonium was $82 \pm$ $7,5 \pm 3$, and $13 \pm 6 \%$ of the total nitrogen uptake, respectively. For the $<5 \mu \mathrm{m}$ fraction, these values were $68 \pm 10,17 \pm 11$, and $15 \pm 4 \%$, respectively.

The average particulate molar $\mathrm{C}: \mathrm{N}$ ratio was 6.3 along the transect.

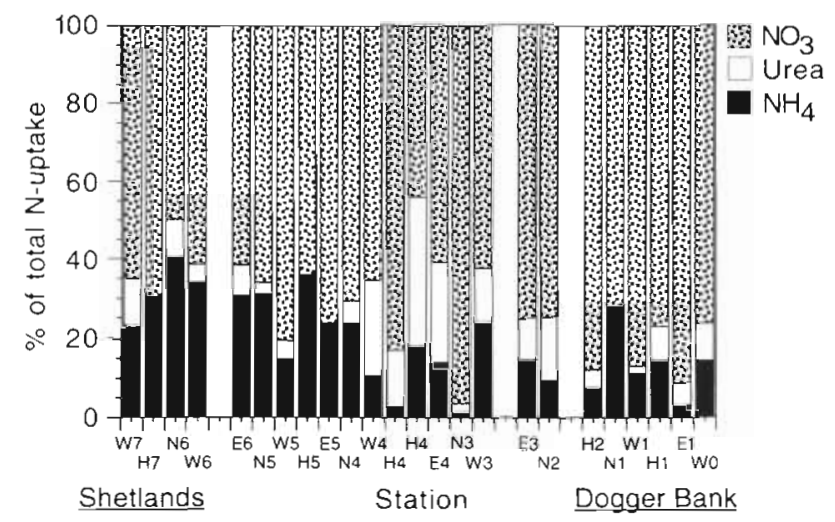

Fig. 3. Relative uptake rates of nitrate, urea, and ammonium, calculated as a fraction of the total nitrogen uptake rate, by the total communities at the different stations 


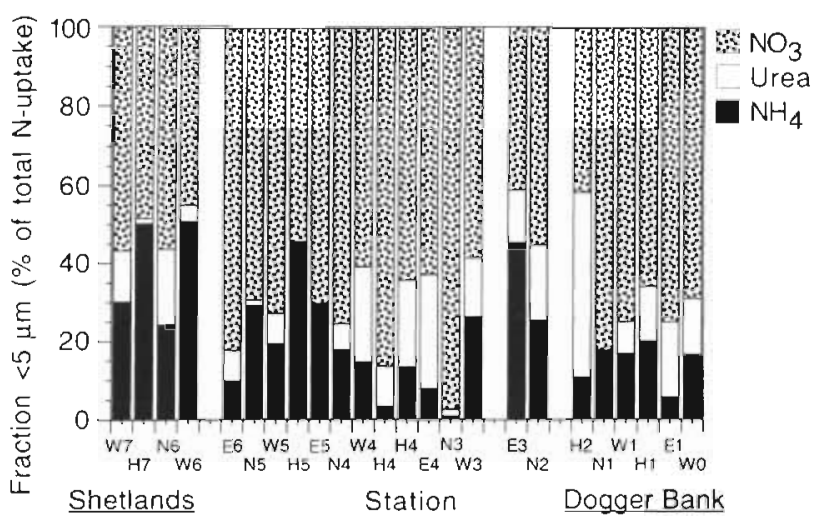

Fig. 4. Relative uptake rates of nitrate, urea, and ammonium, calculated as a fraction of the total nitrogen uptake rate, by the $<5 \mu \mathrm{m}$ fraction at the different stations

Primary production, actually reflecting gross carbon fixation rates due to the relatively short incubation time (i.e. 2 h), showed a somewhat scattered pattern (Fig. 5). Unfortunately, due to technical problems at the beginning of the cruise, no measurements were performed at the peak of the bloom. Along the entire transect, the average carbon fixation rate for the total community was $0.42 \pm 0.11 \mathrm{~g} \mathrm{C} \mathrm{m}^{-2} \mathrm{~d}^{-1}(\mathrm{n}=20)$. The carbon fixation rates were more or less evenly distributed over the 2 size fractions $>5 \mu \mathrm{m}$ and $<5 \mu \mathrm{m}$ at Stns H4 to W7 (Table 1). Closer to the Dogger Bank in some cases the $>5 \mu \mathrm{m}$ fraction was more productive, whereas at other stations the $<5 \mu \mathrm{m}$ fraction exhibited higher carbon fixation rates. Along the entire transect, average carbon fixation rates were $0.23 \pm 0.06 \mathrm{~g} \mathrm{C} \mathrm{m}^{-2}$ $\mathrm{d}^{-1}(\mathrm{n}=20)$ for the $<5 \mu \mathrm{m}$ fraction (Fig. 6) and $0.20 \pm$ $0.09 \mathrm{~g} \mathrm{C} \mathrm{m}^{-2} \mathrm{~d}^{-1}(\mathrm{n}=20)$ for the $>5 \mu \mathrm{m}$ size fraction.

Relating nitrogen uptake rates and carbon fixation rates to algal biomass yielded estimates of specific algal growth rates along the transect. The average algal growth rate along the transect (based on nitrogen up-

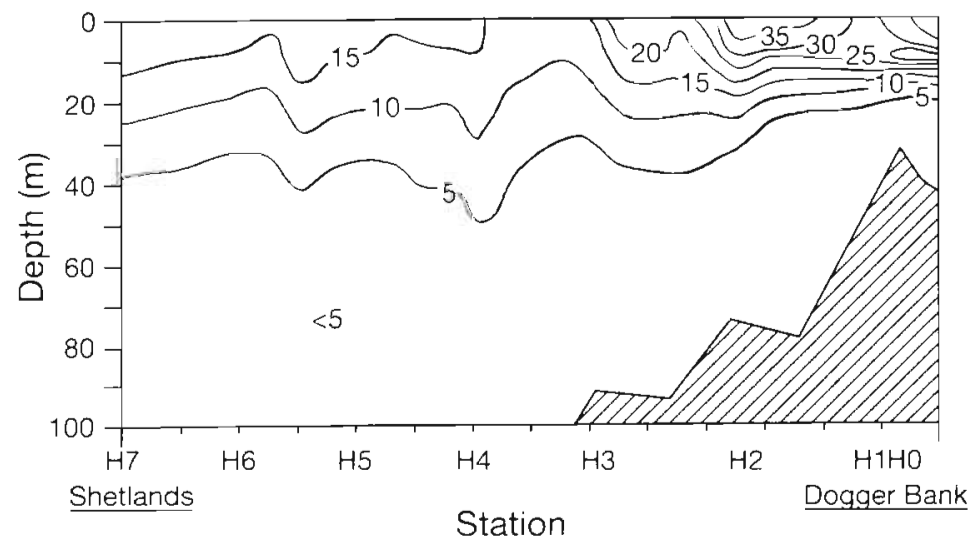

Fig 5. Gross carbon fixation rates ( $\mathrm{mg} \mathrm{C} \mathrm{m}^{-3} \mathrm{~d}^{-1}$ ) by the total algal communities along the transect take and presented as $\mu_{\mathrm{N}}$ in Fig. 7) was $0.27 \pm 0.11 \mathrm{~d}^{-1}$ $(\mathrm{n}=36$ ) for the smaller size fraction with a maximum value of $0.73 \mathrm{~d}^{-1}$. The larger size fraction had a significantly $(p<0.0005)$ lower average specific growth rate $\left(0.17 \pm 0.11 \mathrm{~d}^{-1}\right)$ with a maximum value of $0.70 \mathrm{~d}^{-1}$.

The chl a specific carbon uptake rates $\left(\mu_{C}\right)$ yielded estimates of the specific growth rate which were comparable to the $\mu_{\mathrm{N}}$ values (Fig. 8). Except for 2 stations (H6 \& E4), again a higher specific growth rate $\left(\mu_{C}\right)$ for the smaller size fraction was found $\left(0.29 \pm 0.10 \mathrm{~d}^{-1}\right.$ [ $n=28]$ versus $0.15 \pm 0.05 \mathrm{~d}^{-1}[\mathrm{n}=28]$ for the $>5 \mu \mathrm{m}$ size fraction).

Since the calculated specific growth rates, based on either nitrogen uptake or inorganic carbon uptake, were in good agreement with each other for both size fractions, it was concluded that smaller algae apparently grew faster than larger ones in this typically light-controlled environment. However, the larger species dominated the bloom at the Dogger Bank.

The primary production, defined as the daily biomass production by phytoplankton, was calculated from the specific phytoplankton growth rate (averaged values for estimates from carbon and nitrogen uptake) and the actual biomass of the populations. Along the entire transect, the primary production did not vary to a large extent. Average values for the $<5 \mu \mathrm{m}$ fraction and the total populations were 140 and $265 \mathrm{mg} \mathrm{C} \mathrm{m}^{-2} \mathrm{~d}^{-1}$, respectively. At one station (W0), located over the Dogger Bank and having a water column of only $30 \mathrm{~m}$, primary production was 140 and $1440 \mathrm{mg} \mathrm{C} \mathrm{m}^{-2} \mathrm{~d}^{-1}$, respectively, for the $<5 \mu \mathrm{m}$ fraction and the total community.

\section{DISCUSSION}

Prior to the spring bloom period, the plankton community in the northern part of the North Sea experienced high nutrient concentrations, a low temperature $\left(5.7\right.$ to $\left.7.7^{\circ} \mathrm{C}\right)$, and a mixed water column where a part of the community was frequently exchanged between the upper photic zone (ca $50 \mathrm{~m}$ ) and the deeper, dark part of the water masses. Typical winter values for primary production in the area are in the order of $0.2 \mathrm{~g} \mathrm{C} \mathrm{m}^{-2} \mathrm{~d}^{-1}$ (Richardson \& Heath 1990). According to our measurements, primary production had increased slightly (to $0.26 \mathrm{~g} \mathrm{C} \mathrm{m}^{-2} \mathrm{~d}^{-1}$ ) in April. At the prevailing temperature, the length of the light period $\left(12 \mathrm{~h} \mathrm{~d}^{-1}\right)$, and saturating irradiance and nutrients levels, algae can achieve a growth rate of ca $0.7 \mathrm{~d}^{-1}$ (van Boekel 1992). The observed specific growth rates $(0.17$ to $0.32 \mathrm{~d}^{-1}$ ) of the natural populations were much lower Most likely, the low incident 


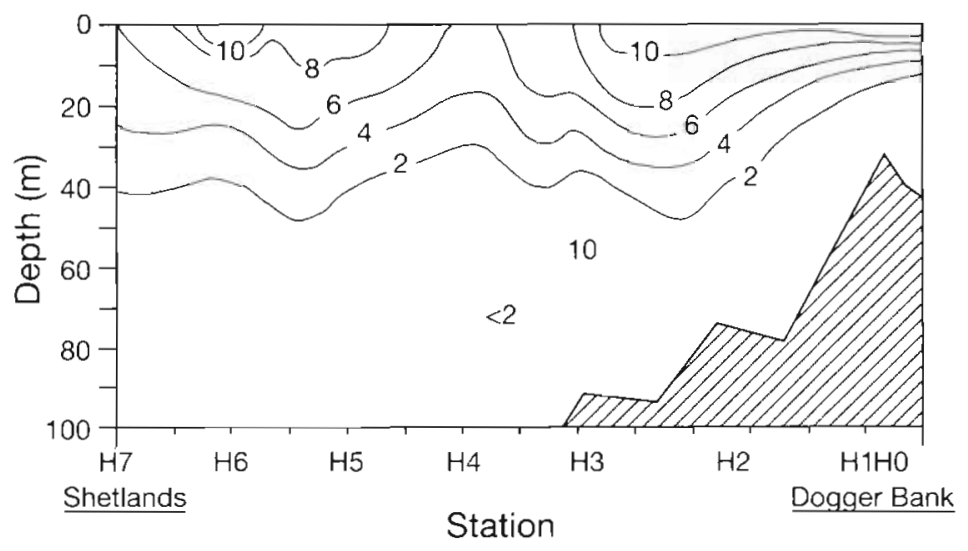

Fig. 6. Gross carbon fixation rates $\left(\mathrm{mg} \mathrm{C} \mathrm{m}^{-3} \mathrm{~d}^{-1}\right)$ by the $<5 \mu \mathrm{m}$ fraction of the communities along the transect

irradiance, in combination with deep mixing, provided light-limitation of phytoplankton growth. Consequently, growth was still light-limited. The critical depth at which photosynthesis equals respiration is determined by the depth-averaged, vertically integrated irradiance (Townsend et al. 1992). Increasing solar elevation in spring enhances the critical depth. Intersection with the bottom (or a newly developed thermocline) prevents mixing into deeper dark layers, thereby reducing respiratory losses. This is why at shallower stations (such as over the Dogger Bank) an earlier onset of the spring bloom and higher algal biomasses were observed. Assuming comparable incident PAR values at all stations, it must be concluded that this energy input was converted into algal biomass production (Fig. 9) with a rather constant efficiency, regardless of the thickness of the water column. In the absence of a deep dark lower layer at Stns 1 and 2, a higher algal biomass could be maintained compared to Stns H3 to W7.

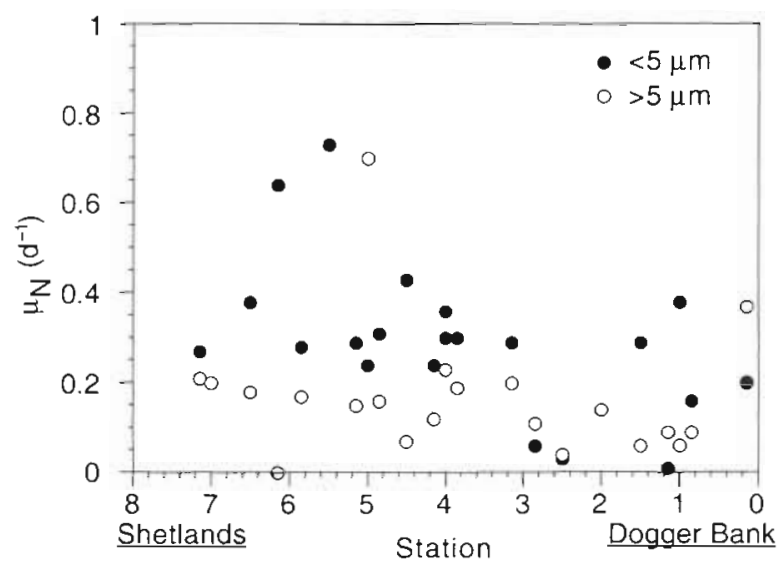

Fig. 7. Specific growth rate of phytoplankton, calculated on the basis of nitrogen uptake $\left(\mu_{N}\right)$, for algae $<5 \mu \mathrm{m}(\bullet)$ and the total phytoplankton communities (o)
The specific growth rates, estimated from carbon uptake, were in good agreement with the estimations from independent nitrogen uptake measurements. However, it should be mentioned that both types of estimations of the specific algal growth rate depend strongly on the conversion factors used in the calculation. So the real $\mu_{\mathrm{N}}$ and $\mu_{\mathrm{C}}$ may have been different from the estimates presented here. Independent of the conversion factors are the trends along the transect and the differences in $\mu_{N}$ and $\mu_{\mathrm{C}}$ between the 2 size fractions. Both methods showed similar trends, which allows the statements on size differential growth rates.

Qualitative microscopical observations indicated the dominance of diatoms. This was also indicated by the nutrient profiles along the transect. Assuming that, prior to the spring bloom, silicate and nitrate concentrations near the Dogger Bank were identical to the concentrations at Stns 3 and 4 (where the spring bloom had not yet started), it can be calculated from the consumed nitrate how much silicate would have been consumed if all algae had been diatoms. In another study, Mills et al. (1994) observed molar nitrate:silicate consumption ratios during the establishment of the diatom spring bloom of 1.9 in the central North Sea and 2.1 in the southern North Sea. These values are close to the average chemical composition (ratio is 2.06) of marine diatoms (Healy 1971). The difference in silicate concentration between Stns $3 \& 4$ and $0 \& 1$ was $3.5 \mu \mathrm{M}$. This corresponds with a consumption of $7.2 \mu \mathrm{mol}$ nitrate $\mathrm{l}^{-1}$. The difference in nitrate concentration between Stns $3 \& 4$ and $0 \& 1$ was $8.7 \mu \mathrm{M}$. This indicates that $83 \%$ of the new production was in the form of diatom biomass. The dominance of diatoms in spring blooms is a well known phenomenon. Usually, their dominance is explained by their

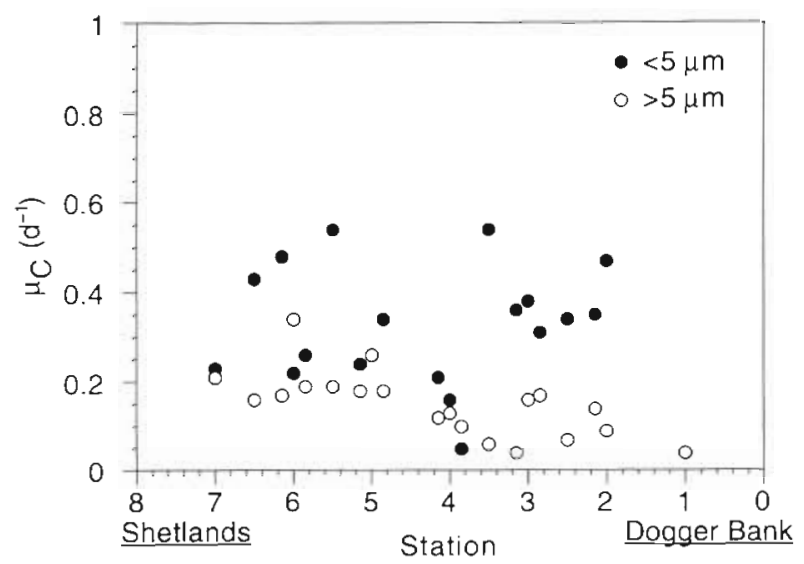

Fig. 8. Specific growth rate of phytoplankton, calculated on the basis of inorganic carbon uptake $\left(\mu_{\mathrm{C}}\right)$, for algae $<5 \mu \mathrm{m}(\bullet)$ and the total phytoplankton communities $(O)$ 


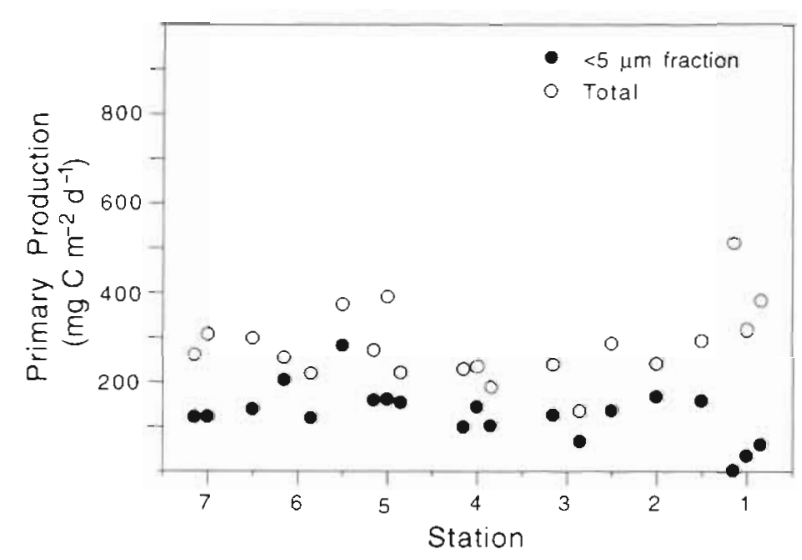

Fig. 9. Primary production of the total phytoplankton communities $(0)$ and the $<5 \mu \mathrm{m}$ size fraction ( $\bullet$ ), calculated as the product of algal biomass and their specific growth rates estimated from nitrogen and carbon uptake, along the transect

high maximum growth rate $\left(\mu_{\max }\right)$ compared to other taxonomical groups (Chisholm 1992). Here, we show that the spring bloom is established under nonsaturating, light-limiting conditions. In such an environment, species are not selected for their $\mu_{\max }$ but for their affinity to light (Huisman 1997). Since marine diatoms are good competitors compared to nondiatoms under light-limiting conditions in the presence of nitrate and silicate (Riegman et al. 1996), they become dominant during the establishment of the spring bloom.

There are large and small diatom species. Size-fractionated chl a measurements indicated the dominance of larger species in the bloom despite the fact that they were growing slower than the smaller ones. Biomass dynamics in natural populations are determined by gain and loss factors. In an earlier study (Riegman et al. 1993) we showed how a spring bloom in a coastal area of the North Sea was established in the presence of substantial grazing by microzooplankton on smaller algae resulting in biomass accumulation of the larger algal species. Indeed, a higher microzooplankton grazing activity was observed at the stations in the bloom (Kuipers \& Witte 1998). Apparently, size-differential control of phytoplankton plays an important role in light-controlled systems.

Although considerable inter- and intra-species specific variations in the $\mathrm{C}: \mathrm{N}$ ratio have been observed in mono-algal cultures (Biddanda \& Benner 1997), the $C: N$ ratio along the transect was fairly constant and was only slightly lower (6.3) than the Redfield ratio (6.6). This ratio appears to be remarkably conservative in the sea (Takahashi et al. 1985, Karl et al. 1993).

The speciation of nitrogen uptake indicated the importance of nitrate as main nitrogen source for phytoplankton. Bacterial production varied from $15 \mathrm{mg} \mathrm{C}$

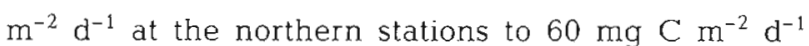
at Stns 0 \& 1 (Kop pers. comm.). These values at the northern and southern locations were equivalent to $6 \%$ and $23 \%$, respectively, of the local primary production by the $<5 \mu \mathrm{m}$ fraction. Expressed as $\%$ of the total primary production these figures were $3 \%$ and $9 \%$. This indicates that the majority of the measured nitrogen uptake rates could be attributed to phytoplankton. This is clearly different from nutrient controlled systems where ammonium uptake by bacteria can have a significant effect on size-differential $f$-ratios for nitrogen uptake (Probyn 1985). In agreement with other field studies (Probyn 1985, Owens et al. 1990) we also observed nitrogen resource partitioning between the algae of different size classes, indicating that the larger algae exhibited a lower preference for regenerative nitrogen than the smaller species. This was observed at the stations ( $\mathrm{H} 0$ to $\mathrm{N} 2$ ) where the phytoplankton was dominated by larger species and the phytoplankton was growing towards nitrogen limitation or silicon limitation. So far, a sound positive correlation between nitrate uptake rates and algal size has been demonstrated in nitrogen-limited discontinuously diluted batch cultures (Stolte et al. 1994, Stolte \& Riegman 1995). It might very well be that the size differential uptake of nitrate is not very significant in light-controlled populations, according to the observations at Stns $\mathrm{H} 3$ to W7. In irradiance-controlled Antarctic surface waters, Probyn \& Painting (1985) observed some size differential nitrogen resource partitioning at 3 out of the 5 stations, where the phenomenon was mainly present in the $<1 \mu \mathrm{m}$ fraction, which is dominated by bacteria

In spring 1992 and 1993, new production was 25\% and occasionally up to $50 \%$ in the western Skagerrak area of the North Sea (Karlson et al. 1996). These authors reported that ammonium was taken up twice as fast as urea, which is in close agreement with oui findings. This might indicate that nitrogen is regenerated at least twice as fast by micro- and mesozooplankton than by bacterial degradation and animal secretion (McCarthy 1982) during spring. We observed new production values up to $80 \%$ in the central North Sea, which is higher than the typical summer values (less than 25\%; Owens et al. 1990), and this is most likely related to nitrate availability.

Our findings consolidate the concept of size differential control of phytoplankton communities under typical spring bloom conditions which originally was demonstrated in a coastal area (Riegman et al. 1993). The spring bloom is established under light-limiting conditions. The specific growth rate of algae is nonsaturated, and the smaller algae grow faster than the larger ones. 
Acknowledgements. We thank the officers and crew of the RV 'Pelagia' for their support during the cruise, and Gerhard J. Herndl for his critical comments on the manuscript. Many thanks go to Rikus Kloosterhuis for assistance with the ${ }^{15} \mathrm{~N}$ analysis, Karel Bakker and Jan van Ooyen for macronutrient analyses, and Harry Witte and Simone Kip for chlorophyll a analyses. Willem Stolte helped in ways too many to be mentioned here. We also thank 3 anonymous referees for their valuable comments.

\section{LITERATURE CITED}

Biddanda B, Benner R (1997) Carbon, nitrogen, and carbohydrate fluxes during the production of particulate and dissolved organic matter by marine phytoplankton. Limnol Oceanogr 42(3):506-518

Blasco D, Packard TT, Garfield PC (1982) Size dependence of growth rate, respiratory electron transport system activity, and chemical composition in marine diatoms in the laboratory. J Phycol 18:58-63

Chan AT (1978) Comparative physiological study of marine diatoms and dinoflagellates in relation to irradiance and cell size. I. Growth under continuous light. J Phycol 14: $396-402$

Chisholm S (1992) Phytoplankton size. In: Falkowski PG, Woodhead AD (eds) Primary productivity and biogeochemical cycles in the sea. Plenum Press, New York. p 213-237

Colijn F (1983) Primary production in the Ems-Dollard estuary. Thesis, Univ Amsterdam

Dugdale RC, Goering JJ (1967) Uptake of new and regenerated forms of nitrogen in primary productivity. Limnol Oceanogr 12:196-206

Epply RW (1972) Temperature and phytoplankton growth in the Sea. Fish Bull US 70:1063-1085

Fisher AE, Harrison PJ (1996) Does carbohydrate content affect the sinking rates of marine diatoms. J Phycol 32(3): $360-365$

Gieskes WWC, Kraay GW (1984) Phytoplankton, its pigments, and primary production at a central North Sea station in May, July, and September 1981. Neth J Sea Res 18(1/2): $51-70$

Grasshoff K (1967) Methods of seawater analysis. VerlagChemie, Weinheim

Helder W, de Vries RTP (1979). An automatic phenolhypochlorite method for the determination of ammonia in sea- and brackish waters. Neth J Sea Res 1.3(1):154-160

Holm-Hansen O, Lorenzen CL, Holmes RW, Strickland JDH (1965) Fluorometric determination of chlorophyll. J Cons Perm Int Explor Mer 30:3-15

Huisman J (1997) The struggle for light. Thesis, Univ Groningen

Karl DM, Tien G, Dorre J, Winn CD (1993) Total dissolved nitrogen and phosphorus concentrations at US-JGOFS station ALOHA: Redfield reconciliation. Mar Chem 41 203-208

Karlson B, Edler L, Granéli W, Sahlsten E, Kuylenstierna M (1996) Subsurface chlorophyll maxima in the Skagerrakprocesses and plankton community structure. J Sed Res $35(1-3): 139-158$

Kierboe T (1993) Turbulence, phytoplankton cell size, and the structure of pelagic food webs. Adv Mar Biol 29:I-72

Koike I, Rönner U, Holm-Eansen O (1981) Microbial nitrogen metabolism in the Scotia Sea. Antarct J US 16:165-166

Kuipers BR, Witte HJ (1998) Grazing impact of microzooplankton on different size classes of algae in the North Sea in early spring and late summer Mar Ecol Prog Ser (in press)

Lüning K (1981) Light. Bot Monogr 17:326-355

Margalef R (1978) Life-forms of phytoplankton as survival alternatives in an unstable environment. Oceanol Acta 1:493-509

McCarthy JJ (1982) The uptake of urea by populations of marine phytoplankton. Limnol Oceanogr 17:738-748

McCarthy JJ, Taylor WR, Taft. JL (1977) Nitrogenous nutrition of the plankton in the Chesapeake Bay. 1. Nutrient availability and phytoplankton preferences. Limnol Oceanogr 22:996-1011

Mills DK, Tett PB, Novarino G (1994) The spring bloom in the south west North Sea in 1989. Neth J Sea Res 33(1):65-80

Moore JK, Villareal TA (1996) Size-ascent relationships in positively buoyant marine diatoms. Limnol Oceanogr 41(7): $1514-1520$

Mortain-Bertrand A, Descolas-Gros C, Jupin H (1988) Pathway of dark inorganic carbon fixation in two species of diatoms: influence of light regime and regulator factors on diel variations. J Plankton Res 10:199-217

Owens NJP, Woodward EMS, Aiken J, Bellan IE, Rees AP (1990) Primary production and nitrogen assimilation in the North Sea during July 1987. Neth J Sea Res 25(1/2): $143-154$

Platt R, Gallegos CL, Harrison WG (1980) Photoinhibition of photsynthesis in natural assemblages of marine phytoplankton. J Mar Res 38:687-701

Probyn TA (1985) Nitrogen uptake by size-fractionated phytoplankton populations in the southern Benguela upwelling system. Mar Ecol Prog Ser 22:249-258

Probyn TA, Painting SJ (1985) Nitrogen uptake by size-fractionated phytoplankton populations in Antarctic surface waters. Limnol Oceanogr 30(6):1327-1332

Raimbault P, Rodier M, Taupier-Letage I (1988) Vertical size distribution of phytoplankton in the western Mediterranean Sea during early summer. Mar Ecol Prog Ser 45 $153-158$

Raven JA (1984) Energetics and transport in aquatic plants MBL lectures in biology 4. Alan R Liss, New York

Rees AP, Owens NJP, Heath MR, Plummer DH, Bellerby RS (1995) Seasonal nitrogen assimilation and carbon fixation in a fjordic sea loch. J Plankton Res 17(6):1307-1324

Richardson K, Heath MR (1990) Primary production and food chain structure in the North Sea during winter, 1987-1988. Br Phycol J 25(1):95

Riegman R (1985) Phosphate-phytoplankton interactions. Thesis, Univ Amsterdam

Riegman R, Colijn F (1991) Evaluation of measurements and calculation of primary production in the Dogger Bank area (North Sea) in summer 1988. Mar Ecol Prog Ser 69: $125-132$

Riegman R, Kuipers BR, Noordeloos AAM, Witte HJ (1993) Size-differential control of phytoplankton and the structure of plankton communities. Neth J Sea Res 31(3): $255-265$

Riegman R, de Boer M, de Senerpont Domis L (1996) Growth of harmful marine algae in multispecies cultures. J Plankton Res 18(10): 1851-1866

Sommer $\mathrm{U}$ (1989) The role of competition for resources in phytoplankton species succession. In: Sommer U (ed) Plankton ecology - successsion in plankton communities. Springer, Berlin, p 57-106

Stolte W. McCollin T, Noordeloos AAM, Riegman R (1994) Effect of nitrogen source on the size distribution within marine phytoplankton populations. J Exp Mar Biol Ecol $184: 83-97$ 
Stolte W, Riegman R (1995) The effect of phytoplankton cell size on transient state nitrate and ammonium uptake kinetics. Microbiology 141:1221-1229

Stolte W, Riegman R (1996) The Relative Preference Index (RPI) for phytoplankton nitrogen use is only weakly related to physiological preference. J Plankton Res 18:1041-1045

Takahashi T, Broecker WS, Langer W (1985) Redfield ratio based on chemical data from isopycnal surfaces. J Geophys Res 90:6907-6924

Taylor AH, Harbour DS, Harris RP, Burkill PH, Edwards ES (1993) Seasonal succession in the pelagic ecosystem of the North Atlantic and the utilization of nitrogen. J Plankton Res 15(8):875-891

Thingstad TF, Sakshaug E (1990) Control of phytoplankton

Editorial responsibility: Otto Kinne (Editor),

Oldendorf/Luhe, Germany growth in nutrient recycling ecosystems. Theory and terminology. Mar Ecol Prog Ser 63:261-272

Townsend DW, Keller MD, Sieracki ME, Ackelson SG (1992) Spring phytoplankton blooms in the absence of vertical water column stratification. Nature 360:59-62

van Boekel W (1992) Interactions of Phaeocystis sp. with organic compounds and the microbial foodweb. Thesis, Univ Groningen

Verity PG (1986) Grazing of phototrophic nanoplankton by microzooplankton in Narrangansett Bay. Mar Ecol Prog Ser 29:105-115

Vermij SG (1987) Analyses of algal growth in Lake Maarsseveen by means of mathematical modelling. Thesis, Univ Amsterdam

Submitted: February 23, 1998; Accepted: July 31, 1998

Proofs received from author(s): October 26, 1998 